\title{
CONTAGION EFFECTS PEREKONOMIAN TIONGKOK DAN PEREKONOMIAN INDONESIA MELALUI JALUR PERDAGANGAN
}

\author{
(Contagion Effects on China's Economy and Indonesia's through Trade Linkage)
}

\author{
Priscilia Calista ${ }^{1}$, Anugerah Karta Monika² \\ Politeknik Statistika STIS ${ }^{1}$ \\ Politeknik Statistika STIS ${ }^{2}$ \\ Jalan Otto Iskandardinata No. 64C, Bidara Cina, Jatinegara, Jakarta Timur \\ E-mail: 15.8821@stis.ac.id
}

\begin{abstract}
ABSTRAK
Contagion effects adalah kondisi ketika timbulnya gejolak ekonomi suatu negara sebagai dampak dari gejolak ekonomi yang terjadi di negara lain. Rebalancing economy yang sedang diupayakan oleh pemerintah Tiongkok mengakibatkan perlambatan pada ekonomi Tiongkok dan tentu akan berdampak pada Indonesia. Penelitian ini bertujuan untuk (1) menganalisis hubungan antara perekonomian Tiongkok dan Indonesia karena Tiongkok merupakan mitra dagang terbesar bagi Indonesia dan Indonesia juga merupakan pasar yang baik bagi Tiongkok, (2) meramalkan kondisi perekonomian Tiongkok dan Indonesia serta (3) menganalisis respon suatu negara terhadap guncangan yang terjadi di negara lain. Penelitian ini menggunakan metode analisis Vector Autoregressive dengan periode tahun 1989-2017. Hasil penelitian meramalkan bahwa pertumbuhan ekonomi kedua negara akan melambat, inflasi kedua negara akan menurun, dan neraca perdagangan Indonesia-Tiongkok akan mengalami surplus pada tahun 2021 dan 2022. Analisis IRF menunjukkan bahwa guncangan pada pertumbuhan ekonomi Tiongkok direspon positif oleh pertumbuhan ekonomi Indonesia dan net export Indonesia-Tiongkok, serta direspon negatif oleh tingkat inflasi Indonesia. Sedangkan guncangan pada pertumbuhan ekonomi Indonesia pada tahun pertama tidak direspon sama sekali oleh pertumbuhan ekonomi Tiongkok, direspon positif oleh tingkat inflasi Tiongkok, dan direspon negatif oleh net export Indonesia-Tiongkok.
\end{abstract}

Kata kunci: contagion effect, net export, VAR, IRF

\begin{abstract}
Contagion effects are conditions when a country's economic turmoil arises as a result of economic shock that occurs in other countries. Rebalancing economy that is being pursued by the China's government has caused a slowdown in the China's economy and will certainly have an impact on Indonesia. This study aims (1) to analyze the relationship between the economies of China and Indonesia because China is the largest trading partner for Indonesia and Indonesia is also a good market for China, (2) to forecast the economic conditions of China and Indonesia and (3) to analyze a country's response to shocks that occur in other countries. . Method used in this research is Vector Autoregressive Analysis with observed variables in 19892017. This research forecasts that these two countries' economy growths will decline, the inflation rate will do too, and Indonesia's net export to China will get surplus in 2021 and 2022. IRF analysis shows that shock on China's economy growth will be responded positively not only by Indonesia's economy growth but also by Indonesia's net export to China, yet responded negatively by Indonesia's inflation rate. Furthermore, shock on Indonesia's economy growth will not be responded by China's economy growth in the first year, responded positively by China's inflation rate, and responded negatively by Indonesia's net export to China.
\end{abstract}

Keywords: contagion effect, net export, VAR, IRF 


\section{PENDAHULUAN}

Indonesia merupakan salah satu negara yang menjalin hubungan internasional dengan banyak negara. Oleh karena itu, kondisi perekonomian di negara lain pasti berdampak pada kondisi perekonomian Indonesia, atau disebut dengan contagion effects (Forbes, 2012). Contagion effects menyebar ke negara lain melalui jalur investasi, remiten, dan perdagangan, namun jalur penularan yang paling dominan bagi Indonesia adalah melalui jalur perdagangan (Tambunan, 2010).

Indonesia merupakan salah satu negara yang melakukan perdagangan internasional dengan berbagai negara untuk mencukupi kebutuhan dan meningkatkan perekonomiannya. Berdasarkan share total ekspor Indonesia, Tiongkok adalah importir terbesar produk-produk Indonesia, yaitu sekitar 14\% yang setara dengan 19,4 miliar USD di tahun 2017. Selain itu, dari total impor Indonesia, ekportir terbesar Indonesia adalah Tiongkok, yaitu sebesar 24,3 miliar USD atau 22\% di tahun 2017. Keterkaitan yang erat antara perekonomian Indonesia dan perekonomian Tiongkok dapat mengakibatkan efek domino, sehingga bila terjadi guncangan atau perubahan pada perekonomian Tiongkok maka akan berdampak pada perekonomian Indonesia dan begitu juga sebaliknya.

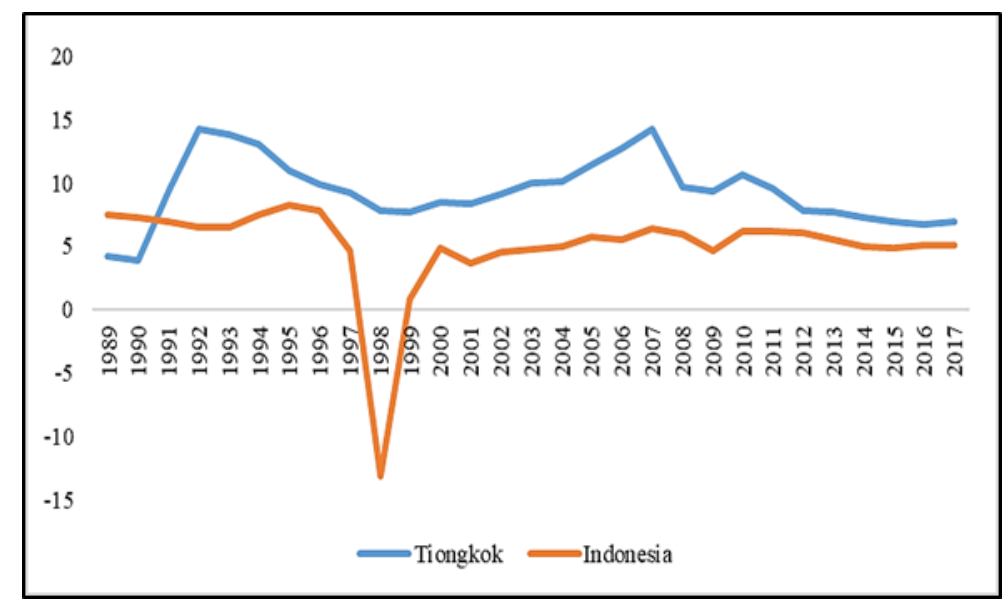

Gambar 1. Pertumbuhan ekonomi Tiongkok dan Indonesia

Pada Gambar 1 dapat dilihat bahwa pertumbuhan ekonomi Tiongkok cenderung berfluktuasi. Peningkatan tajam pertumbuhan ekonomi Tiongkok terjadi dari tahun 1990 dengan pertumbuhan ekonomi sebesar 3,91 persen menjadi 14,21 persen di tahun 1992, dan setelah itu berangsur-angsur menurun. Peningkatan tajam ini disebabkan oleh reformasi tahap kedua perekonomian Tiongkok yang dilakukan di era akhir 1980-an hingga awal 1990-an. Pada tahun 2007, pertumbuhan ekonomi Tiongkok mencapai titik tertingginya, yaitu sebesar 14,23 persen. Namun, setelah tahun 2007, pertumbuhan ekonomi Tiongkok cenderung menurun. Pada tahun 2016, pertumbuhan ekonomi Tiongkok turun menjadi sebesar 6,7 persen dan ini merupakan pertumbuhan ekonomi terendah yang pernah dialami Tiongkok sejak tahun 1990.

Pertumbuhan ekonomi Tiongkok yang melambat awalnya dikarenakan krisis global pada tahun 2008. Setelah krisis global yang mengakibatkan permintaan eksternal runtuh, Tiongkok beralih dari ekonomi berbasis ekspor menjadi berbasis investasi untuk mengembalikan pertumbuhan ekonominya. Kebijakan ini menyebabkan perekonomian sangat bergantung pada kredit untuk menghasilkan pertumbuhan ekonomi. Investasi berlebihan yang terjadi secara terus-menerus akan meningkatkan hutang hingga pada tingkat yang tidak berkelanjutan dengan peningkatan risiko krisis keuangan. Oleh karena itu, pemerintah Tiongkok menetapkan kebijakan rebalancing economy. Rebalancing yang dilakukan Tiongkok adalah mengalihkan investasi menjadi konsumsi domestik serta transisi dari ekonomi berbasis industri menjadi berbasis jasa. Kebijakan inilah yang menyebabkan terjadinya perlambatan ekonomi Tiongkok (Zhang, 2016). Kondisi perekonomian Tiongkok terus menunjukkan perlambatan hingga tahun 2016 sebesar 6,7\%. Kondisi ini merupakan pertumbuhan ekonomi terendah yang pernah dialami Tiongkok sejak 1990 . Hal ini berbeda dengan pertumbuhan ekonomi Indonesia yang cenderung stagnan di kisaran 4\%-6\% sejak tahun 2007. Perubahan-perubahan dari perekonomian Tiongkok tentu saja berdampak pada daya beli dan perdagangan internasional yang dilakukan antara Tiongkok dengan negara lain, termasuk Indonesia. 
Balasubramaniam et al (2012) melakukan penelitian dengan tujuan menguji hubungan interdependensi antara negara ASEAN-5 (Indonesia, Malaysia, Filipina, Singapura, dan Thailand) dan Tiongkok dari perspektif siklus bisnis. Penelitian ini menggunakan metode analisis VAR dan koefisien korelasi dengan variabel PDB nominal dalam miliar USD untuk keenam negara tersebut. Berdasarkan hasil penelitian ini, terdapat korelasi yang kuat dan positif antara siklus bisnis Tiongkok dan siklus bisnis ASEAN-5. Selain itu, dengan model VAR diketahui bahwa terdapat tiga hubungan dua arah dalam model ini. Hubungan dua arah tersebut terjadi antara Tiongkok dan Indonesia, Tiongkok dan Filipina, serta Tiongkok dan Singapura. Dalam penelitian yang dilakukan oleh Febria Ramana (2017), didapatkan hasil bahwa PDB, inflasi, dan tingkat suku bunga Amerika Serikat dan Tiongkok memiliki trend yang cenderung searah dengan Indonesia, sedangkan kurs memiliki trend berlawanan arah. Hal ini menunjukkan adanya keterkaitan yang kuat antara perekonomian Amerika Serikat dan Tiongkok dengan Indonesia. Selain itu, berdasarkan analisis dengan simulasi model persamaan simultan, diketahui bahwa dampak terbesar yang diterima Indonesia adalah berasal dari Tiongkok. Harahap et al (2015) dalam penelitiannya yang berjudul Dampak Spillover Shock Eksternal pada Perekonomian Indonesia: Pendekatan Global VAR mengkaji dampak dari beberapa jenis eksternal shocks terhadap variabel makroekonomi Indonesia. Hasil penelitian ini menunjukkan pertumbuhan ekonomi Tiongkok merupakan eksternal shock utama yang memengaruhi pertumbuhan ekonomi Indonesia jika dibandingkan dengan simulasi shock yang lain.

Berdasarkan pemaparan di atas, perlu dilakukan peramalan dinamis kondisi perekonomian Tiongkok dan Indonesia untuk mengetahui perkembangan perekonomian kedua negara. Selain itu, perlu dilakukan analisis respon dari perekonomian satu negara terhadap guncangan yang terjadi pada perekonomian negara lain.

\section{METODE}

\section{Landasan Teori}

\section{Contagion Effects}

Contagion effects dapat diakibatkan oleh sejumlah faktor fundamental. Berikut kelompok yang termasuk dalam faktor fundamental penyebab terjadinya contagion effects (Claessens dan Forbes, 2004):

1. Common atau global shock. Contoh-contoh dari common shock adalah perubahan suku bunga, nilai mata uang, harga komoditas, dan penurunan pertumbuhan ekonomi. Hal ini dapat memicu krisis karena adanya perpindahan arus modal dan perubahan harga aset.

2. Trade linkages. Faktor ini bisa terjadi dalam bentuk perdagangan langsung dan competitive devaluations. Krisis yang terjadi di suatu negara akan mengurangi pendapatan negara tersebut dan mengurangi permintaan akan barang impor. Kejadian ini akan berdampak pada penurunan ekspor, neraca perdagangan, dan hal lain terkait perekonomian dari negara lain. Ditambah lagi, jika krisis tersebut menyebabkan negara harus mendevaluasi nilai mata uangnya, ini akan mereduksi ekspor negara lain karena relatif harga yang lebih mahal sehingga akan memaksa negara lain untuk mendevaluasi nilai mata uang juga. Hal ini disebut competitives devaluations.

3. Financial linkages. Krisis yang terjadi di suatu negara akan berpengaruh langsung terhadap keuangan negara lain. Pengaruh ini ditransmisikan melalui reduksi kredit perdagangan, penanaman modal asing, dan arus modal lainnya. Reduksi pada aliran modal masuk dapat menekan kurs untuk terdepresiasi.

Penelitian ini menganalisis contagion effects yang disebabkan oleh trade linkages karena menurut Tambunan (2010), jalur penularan krisis yang paling dominan bagi Indonesia adalah melalui jalur perdagangan. 


\section{Teori Permintaan}

Teori permintaan menjelaskan hubungan antara jumlah permintaan suatu barang dan jasa dengan harga. Menurut Sukirno (2004), permintaan masyarakat kepada suatu barang ditentukan oleh banyak faktor, seperti:

1. Harga barang itu sendiri

2. Harga barang lain yang berkaitan erat dengan barang tersebut

3. Pendapatan

4. Distribusi pendapatan

5. Selera

6. Jumlah penduduk

7. Ramalan mengenai keadaan yang akan datang

\section{Metode Pengumpulan Data}

Dalam penelitian ini, data yang digunakan merupakan data sekunder berupa data time series dengan periode tahunan dari tahun 1989 hingga 2017. Data PDB Indonesia, PDB Tiongkok, IHK Indonesia, dan IHK Tiongkok diperoleh dari World Bank, sedangkan data nilai ekspor Indonesia ke Tiongkok dan nilai impor Indonesia dari Tiongkok diperoleh dari UN Comtrade. Berikut definisi operasional yang digunakan dalam variabel-variabel penelitian:

1. Pertumbuhan ekonomi adalah persentase perubahan pendapatan atau PDB riil dari tahun ke tahun. Pertumbuhan ekonomi didekati dengan logaritma natural dari PDB riil.

2. Inflasi adalah persentase perubahan harga-harga yang berlaku dalam perekonomian negara pada suatu waktu tertentu. Inflasi didekati dengan logaritma natural dari IHK.

3. Net export adalah selisih antara ekspor dan impor suatu negara pada waktu yang sama. Net export didekati dengan selisih ekspor Indonesia ke Tiongkok dan impor Indonesia dari Tiongkok.

\section{Metode Analisis}

Penelitian ini menggunakan analisis inferensia dengan metode Vector Auto Regression (VAR) untuk melakukan peramalan pertumbuhan ekonomi Tiongkok dan Indonesia, inflasi Tiongok dan Indonesia, serta net export Indonesia-Tiongkok tahun 2018-2022. Selain itu, metode VAR juga digunakan untuk melihat respon dari perekonomian Indonesia jika terjadi shock pada pertumbuhan ekonomi Tiongkok serta respon dari perekonomian Tiongkok jika terjadi shock pada pertumbuhan ekonomi Indonesia. Adapun tahapan dalam melakukan analisis inferensia dengan model VAR pada penelitian ini adalah sebagai berikut:

a. Uji Stasioneritas

Pengujian stasioneritas data dilakukan menggunakan Augmented Dickey-Fuller Test.

b. Penentuan lag optimum

Penentuan panjang lag optimum dilakukan dengan mempertimbangkan beberapa kriteria, antara lain Akaike Information Criterion (AIC), Schwartz Information Criterion (SIC), HannanQuinn Criteria (HQ), Likelihood Ratio (LR), Final Predictor Error (FPE).

c. Uji stabilitas model

Model VAR dikatakan stabil jika memiliki modulus kurang dari satu atau dengan kata lain, semua roots berada pada unit circle. Jika model VAR yang dihasilkan tidak stabil, maka analisis lebih lanjut dalam VAR, seperti Impulse Response Function (IRF) dan Forecast Error Variance Decomposition (FEVD) tidak dapat dilakukan atau menjadi tidak valid jika digunakan (Enders, 2014).

d. Estimasi model VAR

Koefisien yang dihasilkan dalam persamaan VAR tidak dapat diinterpretasikan secara langsung karena model VAR tidak mengenal dikotomi variabel antara variabel eksogen dan variabel endogen (Johansen, 2012).

e. Pengujian asumsi klasik

Pengujian asumsi klasik yang dilakukan dalam penelitian ini adalah uji normalitas, uji homoskedastisitas, dan uji non-autokorelasi.

f. Peramalan dengan model VAR 
Variabel yang akan diramalkan adalah pertumbuhan ekonomi dan inflasi Tiongkok dan Indonesia serta net export Indonesia-Tiongkok.

g. Analisis Impulse Response Function (IRF)

IRF merupakan teknik penelusuran pengaruh guncangan (shock) sebesar satu standar deviasi yang dialami oleh satu variabel di dalam sistem terhadap nilai-nilai semua variabel saat ini dan beberapa periode mendatang. IRF juga digunakan untuk melihat seberapa lama suatu variabel menjadi stabil kembali setelah terkena dampak guncangan.

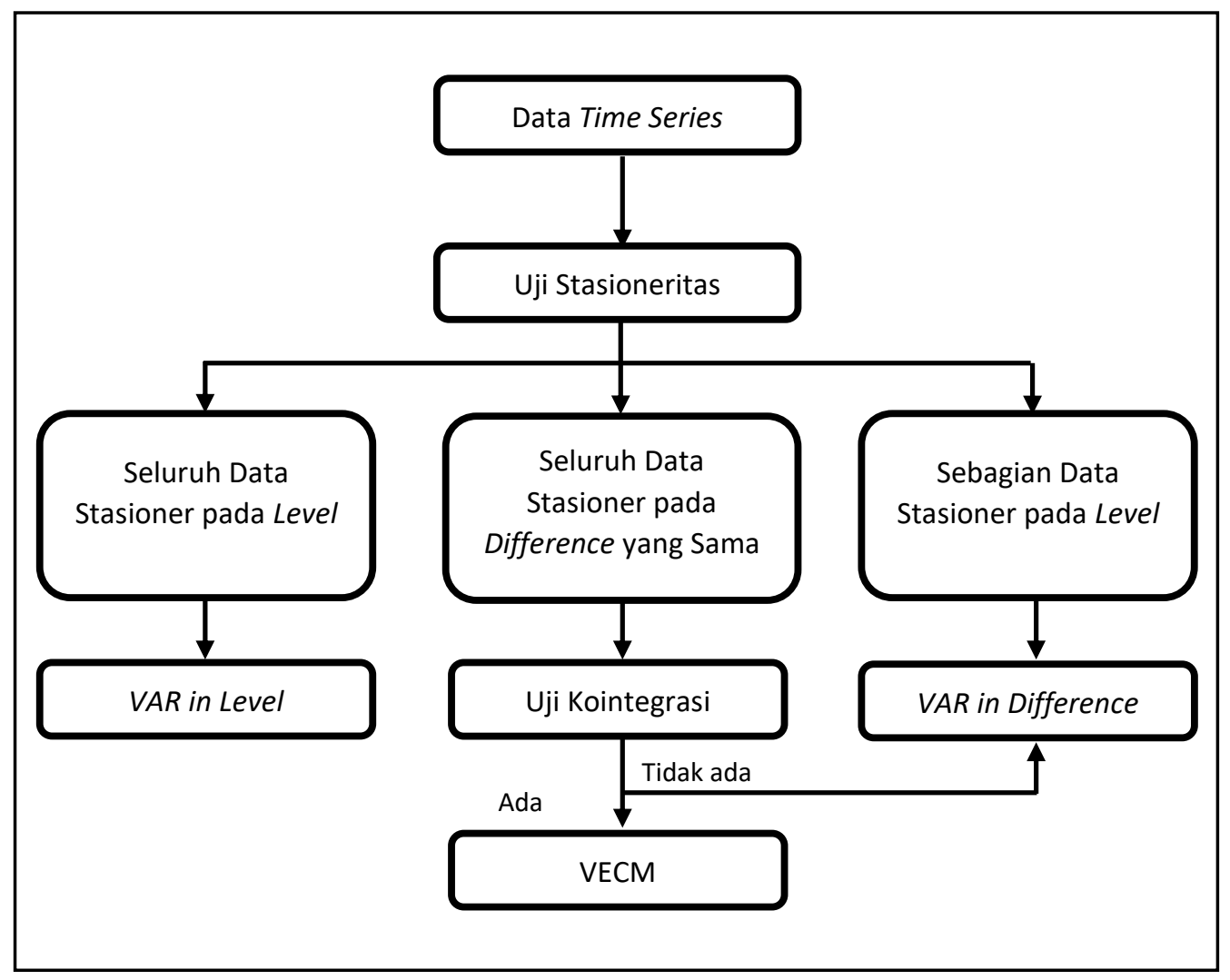

Gambar 2. Alur tahapan analisis VAR

\section{HASIL DAN PEMBAHASAN}

\section{Peramalan}

Untuk menjawab tujuan penelitian mengenai kondisi perekonomian Tiongkok dan Indonesia di masa yang akan datang, maka dilakukan peramalan menggunakan model VAR yang telah dibentuk. Dari model yang terbentuk, digunakan untuk peramalan 5 tahun ke depan dengan hasil demikian.

Tabel 1. Hasil peramalan perekonomian Tiongkok dan Indonesia tahun 2018-2022

\begin{tabular}{|c|c|c|c|c|c|}
\hline Tahun & $\begin{array}{c}\text { Pertumbuhan } \\
\text { Ekonomi Tiongkok } \\
\text { (persen) }\end{array}$ & $\begin{array}{c}\text { Pertumbuhan } \\
\text { Ekonomi Indonesia } \\
\text { (persen) }\end{array}$ & $\begin{array}{c}\text { Inflasi } \\
\text { Tiongkok } \\
\text { (persen) }\end{array}$ & $\begin{array}{c}\text { Inflasi } \\
\text { Indonesia } \\
\text { (persen) }\end{array}$ & $\begin{array}{c}\text { Net Export } \\
\text { (USD) }\end{array}$ \\
\hline 2018 & 6,2536 & 4,8117 & 1,90 & 4,77 & $-2,14$ miliar \\
\hline 2019 & 5,9931 & 4,7811 & 1,83 & 4,54 & $-1,47$ miliar \\
\hline 2020 & 5,7419 & 4,7575 & 1,75 & 4,31 & $-0,72 \mathrm{miliar}$ \\
\hline 2021 & 5,4993 & 4,7313 & 1,68 & 4,09 & 0,104 miliar \\
\hline 2022 & 5,2646 & 4,7014 & 1,61 & 3,89 & 1,006 miliar \\
\hline
\end{tabular}

Dari tabel 1, dapat dilihat bahwa model VAR meramalkan laju pertumbuhan ekonomi Tiongkok akan terus menurun, dari tahun 2018 sebesar 6,25 persen menjadi 5,26 persen di tahun 2022 . Perekonomian Tiongkok yang terus melemah ini tentu akan berdampak juga pada pelemahan 
perekonomian Indonesia. Dapat dilihat pada tabel bahwa Indonesia juga mengalami perlambatan dalam laju pertumbuhan ekonomi dari tahun 2018 diramalkan sebesar 4,81 persen menjadi 4,7 persen di tahun 2022. Selain itu, inflasi dari Tiongkok maupun Indonesia diperkirakan mengalami penurunan dari tahun 2018 sampai tahun 2022. Hal yang menarik pada tabel di atas adalah net export Indonesia terhadap Tiongkok diramalkan perlahan-lahan akan menginjak surplus. Setelah sepuluh tahun neraca perdagangan Indonesia dengan Tiongkok selalu defisit, di tahun 2021, net export Indonesia dengan Tiongkok akan surplus sebesar 104.451.355,49 USD. Jumlah surplus dari net export akan meningkat tajam di tahun 2022 menjadi sebesar 1.006.157.011,79 USD.

\section{Impulse Response Function}

Analisis Impulse Response Function digunakan agar dapat mengetahui pengaruh dari shock suatu variabel endogen terhadap variabel endogen lainnya di dalam sistem. Analisis IRF juga dapat menunjukkan lama pengaruh shock suatu variabel terhadap variabel hingga bisa kembali ke keseimbangan.

\section{Respon Perekonomian Indonesia Terhadap Guncangan pada Pertumbuhan Ekonomi Tiongkok}

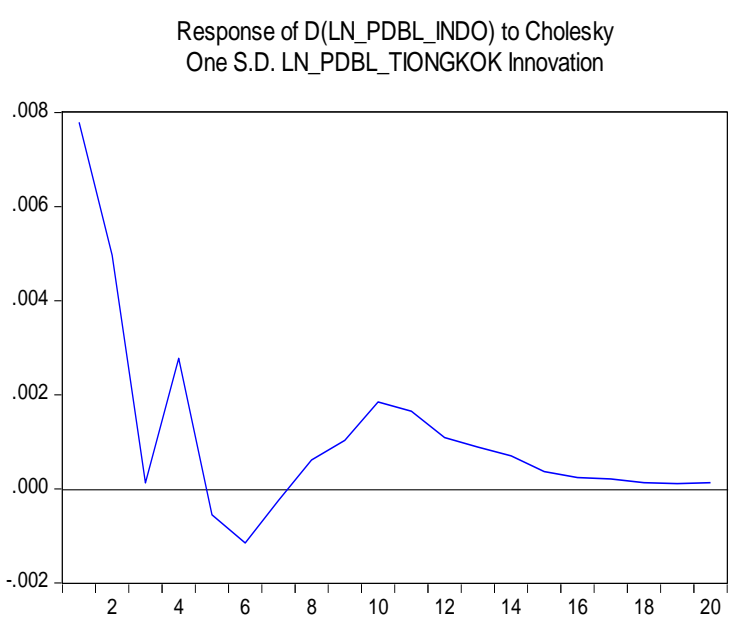

(3a)

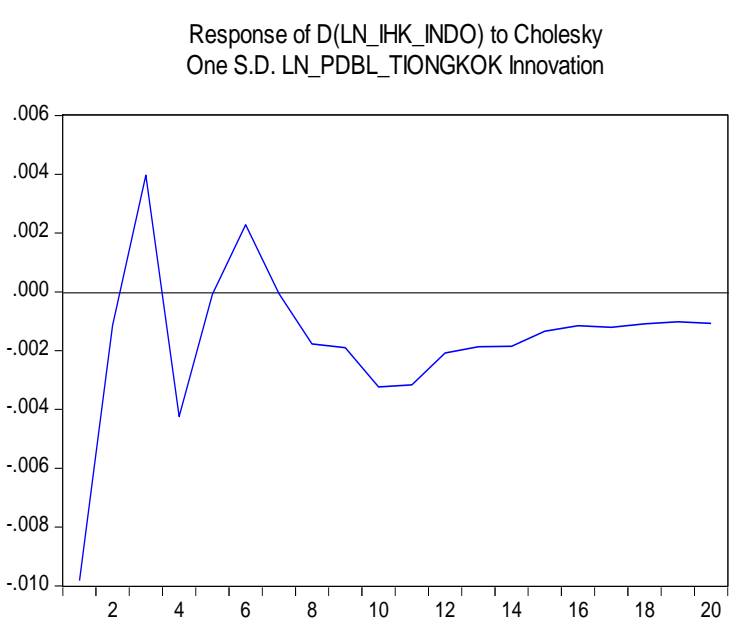

(3b)

Response of D(NETEKSPOR) to Cholesky One S.D. LN_PDBL_TIONGKOK Innovation

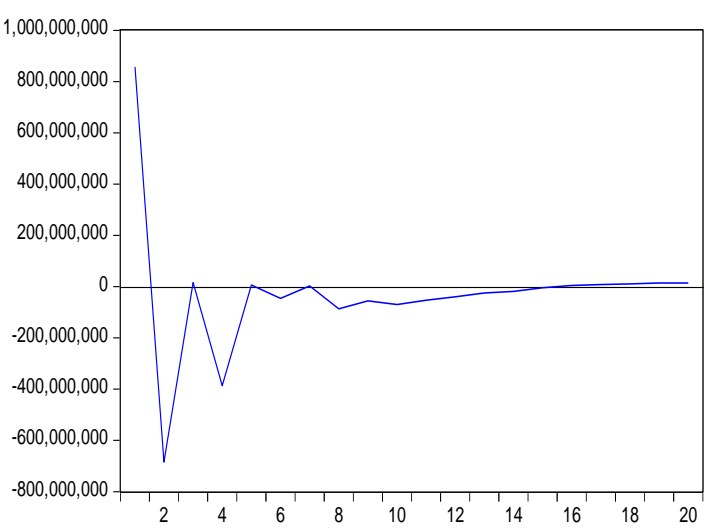

(3c)

Gambar 3. Impulse Response Function Perekonomian Indonesia

Berdasarkan Gambar 3a, dapat dilihat bahwa guncangan/ shock pada pertumbuhan ekonomi Tiongkok sebesar satu standar deviasi pada tahun pertama akan direspon positif oleh pertumbuhan ekonomi Indonesia sebesar 0,0077 persen. Respon pertumbuhan ekonomi Indonesia cenderung berfluktuatif hingga tahun kesepuluh, peningkatan pertumbuhan ekonomi Indonesia mulai menurun terus hingga mencapai keseimbangan baru.

Pada Gambar 3b, guncangan/shock pada pertumbuhan ekonomi Tiongkok sebesar satu standar deviasi pada tahun pertama akan direspon negatif oleh tingkat inflasi Indonesia sebesar 
0,0098 persen. Setelah periode tahun pertama, respon tingkat inflasi Indonesia mulai meningkat secara fluktuatif. Mulai tahun kesepuluh, inflasi Indonesia terus meningkat hingga mencapai keseimbangan baru.

Dalam Gambar 3c, guncangan/shock pada pertumbuhan ekonomi Tiongkok sebesar satu standar deviasi pada tahun pertama akan diresponi positif net export Indonesia-Tiongkok sebesar 857 juta USD. Setelah periode tahun pertama, respon net export Indonesia-Tiongkok mulai menurun secara fluktuatif hingga tahun kesepuluh, pertumbuhan net export berangsur-angsur menuju ke arah positif hingga mencapai keseimbangan baru.

\section{Respon Perekonomian Tiongkok Terhadap Guncangan pada Pertumbuhan Ekonomi Indonesia}

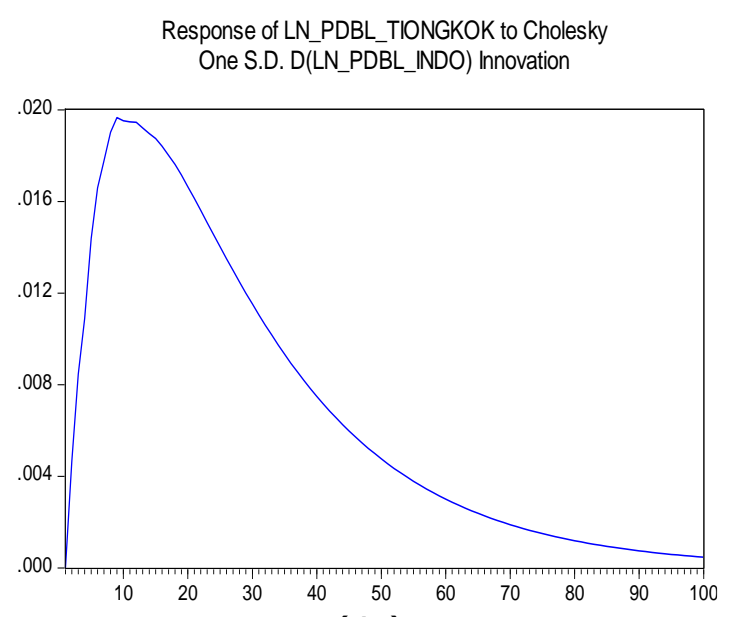

(4a)

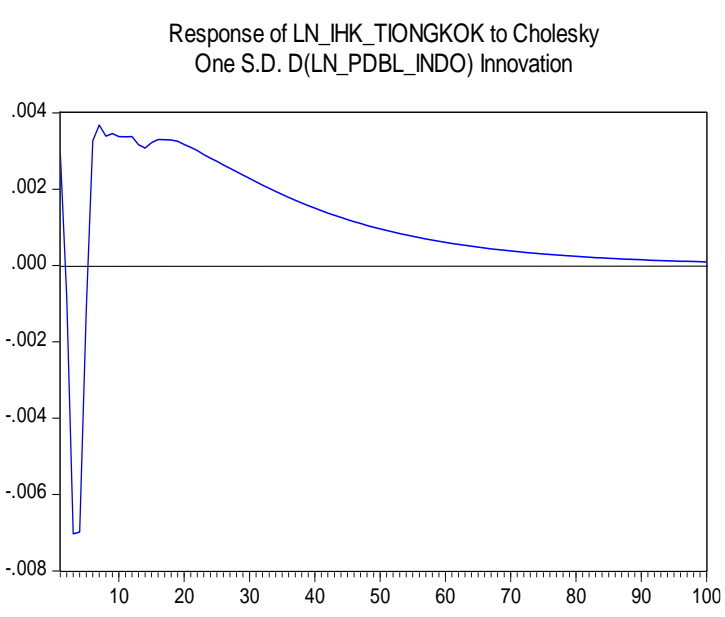

(4b)

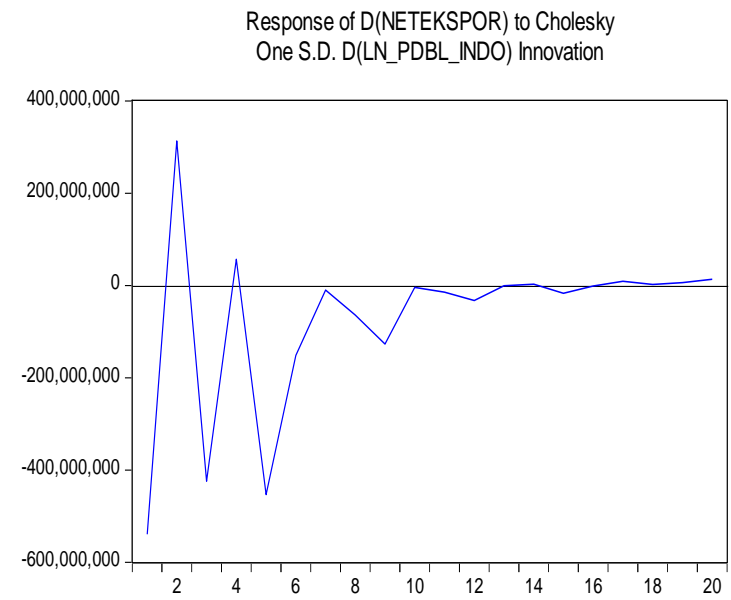

$(4 c)$

Gambar 4. Impulse Response Function Perekonomian Tiongkok

Berdasarkan Gambar 4a, dapat dilihat bahwa guncangan/shock pada pertumbuhan ekonomi Indonesia sebesar satu standar deviasi tidak berdampak atau tidak direspon sama sekali oleh pertumbuhan ekonomi Tiongkok pada tahun pertama. Pada tahun kedua, guncangan pada pertumbuhan ekonomi Indonesia di tahun sebelumnya direspon positif oleh pertumbuhan ekonomi Tiongkok sebesar 0,0025 persen. Pertumbuhan ekonomi Tiongkok terus merespon positif hingga puncaknya pada tahun kesembilan respon dan setelah tahun kesembilan, respon pertumbuhan ekonomi Tiongkok mulai menurun terus hingga mencapai keseimbangan baru.

Pada Gambar 4b, guncangan/shock pada pertumbuhan ekonomi Indonesia sebesar satu standar deviasi pada tahun pertama akan direspon positif oleh tingkat inflasi Tiongkok sebesar 0,003 persen. Guncangan ini membuat laju inflasi Tiongkok menjadi berfluktuasi hingga mulai tahun keenam belas, respon inflasi Tiongkok terus menurun hingga mencapai keseimbangan baru.

Dalam Gambar 4c, guncangan/shock pada pertumbuhan ekonomi Indonesia sebesar satu standar deviasi pada tahun pertama akan direspon negatif oleh net export Indonesia-Tiongkok sebesar 539 juta dolar. Setelah periode tahun pertama, respon net export Indonesia-Tiongkok mulai 
meningkat secara fluktuatif hingga tahun ke-18, pertumbuhan net export berangsur-angsur menuju ke arah positif hingga mencapai keseimbangan baru.

\section{KESIMPULAN}

Hasil peramalan menunjukkan bahwa pertumbuhan ekonomi baik negara Tiongkok maupun negara Indonesia akan mengalami perlambatan dari tahun ke tahun. Selain pertumbuhan ekonomi, laju inflasi dari kedua negara juga mengalami perlambatan. Perkembangan net export IndonesiaTiongkok diramalkan akan mengalami surplus bagi Indonesia di tahun 2021 dan tahun 2022.

Guncangan pada pertumbuhan ekonomi Tiongkok direspon positif oleh pertumbuhan ekonomi Indonesia dan bergerak fluktuatif hingga stabil pada tahun ke-10 setelah guncangan. Guncangan pada pertumbuhan ekonomi Tiongkok direspon negatif oleh inflasi Indonesia dan bergerak fluktuatif hingga pada tahun ke-10 setelah guncangan mulai stabil dan mencapai keseimbangan baru. Guncangan pada pertumbuhan ekonomi Tiongkok direspon positif oleh neraca perdagangan Indonesia-Tiongkok dan bergerak fluktuatif hingga stabil pada tahun ke-10 setelah guncangan.

Guncangan pada pertumbuhan ekonomi Indonesia tidak direspon sama sekali oleh pertumbuhan ekonomi Tiongkok di tahun pertama, kemudian bergerak positif hinga mencapai puncaknya pada tahun ke-9 dan setelah itu berangsur stabil menurun hingga mencapai keseimbangan. Guncangan pada pertumbuhan ekonomi Indonesia direspon positif oleh inflasi Tiongkok dan bergerak fluktuatif hingga tahun ke-16 mulai bergerak stabil menurun untuk mencapai kestabilan setelah guncangan. Guncangan pada pertumbuhan ekonomi Indonesia direspon negatif oleh neraca perdagangan Indonesia-Tiongkok dan bergerak fluktuatif hingga stabil pada tahun ke18 setelah guncangan.

\section{DAFTAR PUSTAKA}

Balasubramaniam, Arunnan et al. (2012). Economic Interdependence: Evidence from China and ASEN-5 Countries. Modern Economy, 2012(1), 122-125.

Claessens, Stijn \& Kristin Forbes. (2004). International Financial Contagion: The Teory, Evidence, and Policy Implications. The IMF's Role in Emerging Market Economies: Reassessing the Adequacy of Its Resources.

Enders, Walter. (2015). Applied Econometric Time Series Fourth Edition. Hoboken: John Wiley \& Sons.

Forbes, Kristin. (2012). The "Big C": Identifying Contagion. Cambridge: National Bureau of Economic Research.

Harahap, dkk. (2015). Dampak Spillover Shock Eksternal Pada Perekonomian Indonesia: Pendekatan Global $V A R$. Jakarta: Bank Indonesia.

Johansen. (2002). The Interpretation of Cointegrating Coefficient in The Cointegrated Vector Autoregressive Model. Copenhagen: University of Copenhagen.

Ramana, Febria. (2017). Contagion Effects Perekonomian Amerika Serikat dan Cina terhadap Perekonomian Indonesia [Skripsi]. Jakarta: Sekolah Tinggi Ilmu Statistik.

Setiawan, Heri \& Lestari, Sari. 2011. Perdagangan Internasional. Yogyakarta: Pustaka Nusantara.

Sukirno, Sadono. (2009). Mikroekonomi Teori Pengantar Edisi Ketiga. Jakarta: Raja Grafindo Perkasa.

Tambunan, Tulus. (2010). The Indonesian Experience with Two Big Economic Crises. Modern Economy, 2010(1), 156-167.

Zhang. (2016). Rebalancing in China-Progress and Prospects. IMF Working Paper \#16/183.

\section{LAMPIRAN}

Lampiran 1. Uji Stasioneritas

\begin{tabular}{|c|l|c|c|c|c|}
\hline \multirow{2}{*}{ No. } & \multirow{2}{*}{ Nama Variabel } & \multicolumn{2}{|c|}{ Level } & \multicolumn{2}{c|}{$1^{\text {st }}$ Difference } \\
\cline { 3 - 6 } & & t-statistics & $\boldsymbol{p}$-value & t-statistics & $\boldsymbol{p}$-value \\
\hline$(1)$ & $(2)$ & $(3)$ & $(4)$ & $(5)$ & $(6)$ \\
\hline 1. & Ln_PDB_Indo & $-0,1724$ & 0,9312 & $-3,8080$ & $0,0077^{*}$ \\
\hline 2. & Ln_PDB_Tiongkok & $-2,9790$ & $0,0497^{*}$ & - & - \\
\hline 3. & Ln_IHK_Indo & $-1,6264$ & 0,4563 & $-4,1272$ & $0,0036^{*}$ \\
\hline 4. & Ln_IHK_Tiongkok & $-4,4298$ & $0,0102^{*}$ & - & - \\
\hline 5. & Net Export & $-1,8991$ & 0,3279 & $-6,0861$ & $0,0000^{*}$ \\
\hline
\end{tabular}

Keterangan: $*$ ) signifikan pada $\mathrm{a}=0,05$ 
Lampiran 2. Pengujian Lag Optimum

\begin{tabular}{|c|c|c|c|c|c|}
\hline Lag & AIC & SIC & HQ & FPE & LR \\
\hline$(1)$ & $(2)$ & $(3)$ & $(4)$ & $(5)$ & $(6)$ \\
\hline 0 & 37,21427 & 37,45805 & 37,28189 & $9,99 e+09$ & NA \\
\hline 1 & 28,04729 & 29,50994 & 28,45297 & 1094325 & 212,1726 \\
\hline 2 & 26,49979 & $29,18132 *$ & 27,24353 & $306420,5 *$ & $49,66502^{*}$ \\
\hline 3 & $25,7137 *^{*}$ & 29,61418 & $26,79558^{*}$ & 329762,5 & 25,07414 \\
\hline
\end{tabular}

Lampiran 3. Stabilitas Model VAR

\begin{tabular}{|c|c|}
\hline Root & Modulus \\
\hline$(1)$ & $(2)$ \\
\hline 0,954456 & 0,954456 \\
\hline 0,866666 & 0,866666 \\
\hline$-0,277176-0,714576 i$ & 0,766449 \\
\hline$-0,277176+0,714576 i$ & 0,766449 \\
\hline $0,628896-0,382893 i$ & 0,736286 \\
\hline $0,628896+0,382893 i$ & 0,736286 \\
\hline $0,226571-0,619354 i$ & 0,659495 \\
\hline $0,226571+0,619354 i$ & 0,659495 \\
\hline$-0,581860$ & 0,581860 \\
\hline 0,265900 & 0,265900 \\
\hline
\end{tabular}

Lampiran 4. Uji Asumsi Klasik

Uji Normalitas

\begin{tabular}{|c|c|c|c|}
\hline Persamaan & $\begin{array}{c}\text { Statistik Jarque- } \\
\text { Berra }\end{array}$ & $\begin{array}{c}\text { Derajat } \\
\text { Bebas }\end{array}$ & p-value \\
\hline$(1)$ & $(2)$ & $(3)$ & $(4)$ \\
\hline 1 & 2,857391 & 2 & 0,2396 \\
\hline 2 & 4,405623 & 2 & 0,1105 \\
\hline 3 & 0,937873 & 2 & 0,6257 \\
\hline 4 & 5,675463 & 2 & 0,0586 \\
\hline 5 & 2,523189 & 2 & 0,2832 \\
\hline Join & 16,39954 & 10 & 0,0888 \\
\hline
\end{tabular}

Uji Homoskedastisitas

\begin{tabular}{|c|c|c|}
\hline Chi-sq & df & p-value \\
\hline$(1)$ & $(2)$ & $(3)$ \\
\hline 309,4555 & 300 & 0,3412 \\
\hline
\end{tabular}

Uji Non-autokorelasi

\begin{tabular}{|c|c|c|}
\hline Lags & LM-Stat & $\boldsymbol{p}$-value \\
\hline$(1)$ & $(2)$ & $(3)$ \\
\hline 1 & 26,06982 & 0,4039 \\
\hline 2 & 15,75390 & 0,9220 \\
\hline
\end{tabular}

Lampiran 5. Estimasi Model VAR

\begin{tabular}{|c|c|c|c|c|c|}
\hline & $\begin{array}{c}\text { Ln PDB } \\
\text { Tiongkok }\end{array}$ & $\begin{array}{c}\text { Ln IHK } \\
\text { Tiongkok }\end{array}$ & $\begin{array}{c}\mathrm{D}(\text { Ln IHK } \\
\text { Indonesia) }\end{array}$ & $\begin{array}{c}\mathrm{D}(\text { Ln PDB } \\
\text { Indonesia) }\end{array}$ & $\begin{array}{c}\mathrm{D}(\text { Net } \\
\text { Export })\end{array}$ \\
\hline$(1)$ & $(2)$ & $(3)$ & $(4)$ & $(5)$ & $(6)$ \\
\hline \multirow{2}{*}{$\begin{array}{c}\text { Ln PDB } \\
\text { Tiongkok } \\
(-1)\end{array}$} & 1,588389 & 0,728720 & 0,485620 & 0,298295 & $-6,04 \mathrm{E}+10$ \\
\cline { 2 - 6 } & 0,15935 & 0,35964 & 1,14136 & 0,56930 & $3.2 E+10$ \\
\cline { 2 - 6 } Ln PDB & $\mathbf{9 , 9 6 7 8 7}$ & $\mathbf{2 , 0 2 6 2 3}$ & $\mathbf{0 , 4 2 5 4 8}$ & $\mathbf{0 , 5 2 3 9 6}$ & $\mathbf{- 1 , 9 0 7 6 2}$ \\
\cline { 2 - 6 } $\begin{array}{c}\text { Tiongkok } \\
(-2)\end{array}$ & $\mathbf{- 0 , 5 8 2 4 7 8}$ & $-0,656390$ & $-0,676509$ & $-0,218634$ & $5,73 E+10$ \\
\cline { 2 - 6 } & $\mathbf{- 3 , 5 8 7 7 8}$ & $\mathbf{- 1 , 7 9 1 4 0}$ & $\mathbf{- 0 , 5 8 1 7 7}$ & $\mathbf{- 0 , 3 7 6 9 4}$ & $\mathbf{1 , 7 7 8 4 0}$ \\
\hline
\end{tabular}




\begin{tabular}{|c|c|c|c|c|c|}
\hline \multirow{3}{*}{$\begin{array}{l}\mathrm{D}(\mathrm{Ln} \text { PDB } \\
\text { Indonesia } \\
(-1))\end{array}$} & 0,454339 & $-0,649472$ & $-2,268128$ & 0,895873 & $1,82 \mathrm{E}+10$ \\
\hline & 0,18093 & 0,40834 & 1,29591 & 0,64640 & $3,6 E+10$ \\
\hline & 2,51115 & $-1,59050$ & $-1,75021$ & 1,38595 & 0,50670 \\
\hline \multirow{3}{*}{$\begin{array}{l}\mathrm{D}(\mathrm{Ln} \text { PDB } \\
\text { Indonesia } \\
(-2))\end{array}$} & $-0,156638$ & $-0,173484$ & 0,765754 & $-0,736974$ & $-8,25 E+09$ \\
\hline & 0,18464 & 0,41671 & 1,32247 & 0,65964 & $3,7 E+10$ \\
\hline & $-0,84836$ & $-0,41632$ & 0,57903 & $-1,11723$ & $-0,22485$ \\
\hline \multirow{3}{*}{$\begin{array}{l}\mathrm{D}(\text { Net } \\
\text { Export } \\
(-1))\end{array}$} & $-1,37 \mathrm{E}-13$ & $4,01 \mathrm{E}-12$ & $7,93 \mathrm{E}-13$ & $-4,31 \mathrm{E}-13$ & -0.239675 \\
\hline & $1,5 E-12$ & $3,5 E-12$ & $1,1 E-11$ & $5,5 E-12$ & 0,30479 \\
\hline & $-0,08903$ & 0,81107 & 0,63362 & $-0,07862$ & $-0,78636$ \\
\hline \multirow{3}{*}{$\begin{array}{c}\mathrm{D}(\text { Net } \\
\text { Export } \\
(-2))\end{array}$} & $-1,48 \mathrm{E}-12$ & $2,77 \mathrm{E}-12$ & $6,86 \mathrm{E}-12$ & $-4,32 \mathrm{E}-12$ & 0,222974 \\
\hline & $1,5 E-12$ & $3,4 E-12$ & $1,1 E-11$ & $5,4 E-12$ & 0,30024 \\
\hline & $-0,98179$ & 0,81107 & 0,63363 & $-0,79957$ & 0,74264 \\
\hline \multirow{3}{*}{$\begin{array}{c}\text { Ln IHK } \\
\text { Tiongkok } \\
(-1)\end{array}$} & $-0,234145$ & 1,542438 & 0,050060 & 0,055240 & $-2,12 \mathrm{E}+09$ \\
\hline & 0,06060 & 0,13677 & 0,43405 & 0,21650 & $1,2 E+10$ \\
\hline & $-3,86376$ & 11,2776 & 0,11533 & 0,25515 & $-0,17589$ \\
\hline \multirow{3}{*}{$\begin{array}{c}\text { Ln IHK } \\
\text { Tiongkok } \\
(-2)\end{array}$} & 1,178935 & $-0,773058$ & 0,315144 & $-0,227170$ & $6,72 \mathrm{E}+09$ \\
\hline & 0,06318 & 0,14260 & 0,45254 & 0,22573 & $1,3 E+10$ \\
\hline & 2,83205 & $-5,42127$ & 0,69638 & $-1,00639$ & 0,53538 \\
\hline \multirow{3}{*}{$\begin{array}{l}\mathrm{D}(\mathrm{Ln} \text { IHK } \\
\text { Indonesia } \\
(-1))\end{array}$} & 0,187891 & $-0,303347$ & $-1,125280$ & 0,467085 & $2,21 \mathrm{E}+09$ \\
\hline & 0,08417 & 0,18996 & 0,60285 & 0,30070 & $1,7 E+10$ \\
\hline & 2,23236 & $-1,59691$ & $-1,86660$ & 1,55333 & 0,13213 \\
\hline \multirow{3}{*}{$\begin{array}{l}\mathrm{D}(\mathrm{Ln} \mathrm{IHK} \\
\text { Indonesia } \\
\quad(-2))\end{array}$} & $-0,087161$ & 0,008603 & $-0,065464$ & $-0,179587$ & $-1,46 E+10$ \\
\hline & 0,09041 & 0,20405 & 0,64757 & 0,32300 & $1,8 E+10$ \\
\hline & $-0,96407$ & 0,04216 & $-0,10109$ & $-0,55599$ & $-0,81450$ \\
\hline \multirow{3}{*}{$\mathrm{C}$} & 0,084562 & $-1,195317$ & 4,487635 & $-1,712798$ & $7,93 E+10$ \\
\hline & 0,21486 & 0,48493 & 1,53897 & 0,76763 & $4,3 E+10$ \\
\hline & 0,39356 & $-2,46492$ & 2,91600 & $-2,23128$ & 1,85923 \\
\hline$R^{2} A d j$ & 0,999803 & 0,991152 & 0,257552 & 0,227522 & 0,080178 \\
\hline
\end{tabular}

Keterangan: tercetak miring (standar error)

tercetak tebal ( $t$-statistics) 